\title{
A Odisseia de Homero e a condição humana
}

\author{
Homer's Odyssey and the human condition
}

\section{Rafael Ruiz}

Professor Associado de História da América

EFLCH-UNIFESP

rafarui@hotmail.com

Resumo: O presente artigo procura olhar para a obra de Homero não como uma narrativa épica sobre a figura de um herói clássico, mas como a tentativa, a primeira tentativa, na verdade, de falar sobre a vida de um homem com a pretensão de discutir a condição humana. A partir da história contada pelo próprio Ulisses, podemos compreender melhor as primeiras percepções sobre a realidade humana, sobre como ser verdadeiramente humano, do ponto de vista da cultura ocidental.

Palavras-chave: Odisseia, Ulisses, condição humana, virtudes humanas

\begin{abstract}
The present article seeks to look at Homer's work not as an epic narrative about the figure of a classic hero, but as the attempt, the first attempt, in fact, to speak about the life of a man with the pretension of discussing the human condition. From the story told by Ulysses himself, we can better understand the first perceptions about human reality, about how to be truly human, from the point of view of Western culture.

Keywords: Odyssey, Ulysses, Human condition, Human virtues
\end{abstract}




\section{Introdução}

A Odisseia não é apenas um grande relato épico, mas é reconhecida também como uma das obras fundantes da Europa. A obra em que, provavelmente pela primeira vez, fez-se uma reflexão profunda sobre a ideia de homem ou, por outras palavras, sobre o que seria viver como um verdadeiro homem.

Jaeger, na sua Paideia, chama a atenção para o sentido que os gregos davam ao conceito de "educação" e de "formação" e, nesse sentido, ressaltava que se tratava de encontrar, tal como o oleiro com a argila ou o escultor com a pedra, a boa forma, a forma verdadeira, por meio da qual se pudesse ir formando o ser humano de maneira humana: "os gregos viram pela primeira vez que a educação tem de ser também um processo de construção consciente" (JAEGER, s/d: 12).

Esse processo formativo do ser humano desenvolver-se-ia, portanto, a partir de um "eidos" ou "ideia", tal como o oleiro ou o escultor dariam forma à sua obra de arte. E, nesse sentido, a Odisseia seria essa primeira ideia configuradora do que seria um ser humano tal como deveria ser.

Ulisses, mais do que o grande herói grego, pode ser visto, então, como o modelo de homem que, de certa forma, serviu de referência para a construção do que costumamos chamar de "civilização ocidental". Trata-se da primeira reflexão feita sobre como se pode viver humanamente a vida humana, ou seja, sobre como o homem pode enfrentar as dificuldades e vicissitudes da sua vida pessoal, familiar e social sem perder a sua dignidade humana, sem desumanizar-se. É a primeira narração que temos, pelo menos no mundo ocidental, sobre o drama da vida.

A trama da Odisseia, mesmo para quem não a tenha lido, conserva-se na nossa memória. É a vida de um homem, chamado Ulisses, que, pela dureza dos acontecimentos, teve de estar longe da sua casa e da sua família por um longo tempo, 20 anos, e dos seus esforços para voltar à sua terra, Ítaca, onde se encontravam seus seres queridos: sua mulher, Penélope; seu filho, Telêmaco, a quem deixou lá recém-nascido e que já devia estar se tornando um homem; seu pai ancião, Laertes, e tantos outros que também lhe queriam bem e, depois de tanto tempo, ainda se recordavam dele: o porqueiro, Eumeu, que tomava conta dos seus porcos e a velha criada, Euricleia, que o viu nascer. 
A vida de Ulisses, quando a olhamos dessa forma, não é muito diferente da nossa própria vida. E, mesmo assim, quando pensamos na obra de Homero, vemo-la como algo muito, mas muito mesmo, distante de nós. Por que isso é assim?

\section{A pré-comprensão na leitura da Odisseia}

Quando alguém hoje se aproxima da leitura da Odisseia, quase que inevitavelmente já vai armado com uma pré-compreensão, construída principalmente durante a época do Romantismo, motivada pela figura do herói.

O herói grego -costuma-se falar- era alguém tão fora do comum, tão excepcional, tão quase sobre-humano, que é verdadeiramente impossível chegar perto de Ulisses e sentir algum tipo de empatia por ele. Vemo-lo como alguém tão quase divino, que praticamente pouco ou nada tem a dizer-nos a nós, míseros e vulgares seres humanos.

É provavelmente por isso que a palavra "odisseia" remete também a qualquer empreendimento difícil, custoso e extremamente complexo de ser realizado. Algo que, em definitiva, só poderia ser realizado precisamente por um herói. E nós não nos reconhecemos como alguém com esse tipo de perfil.

E talvez por essa concatenação de pré-compreensões é que, ao lermos ou comentarmos a obra de Homero, procuramos encontrar as qualidades do herói grego numa época tão, mas tão antiga, muito anterior à Grécia clássica, que olhamos inclusive

para essas qualidades como algo muito distantes do humano. Pensamos, assim, que o máximo que poderá dizer-nos e ensinar-nos será uma série de questões interessantes sobre os valores do mundo antigo. Nesse sentido, o próprio Jaeger, por exemplo, pensa que a Odisseia é o melhor exemplo do que ele mesmo denomina de "ética aristocrática", afirmando que "uma prova da íntima conexão entre a epopeia e o mito é o fato de Homero usar exemplos míticos para todas as situações imagináveis da vida em que um homem pode estar na presença de outro para o aconselhar, advertir, admoestar, exortar e lhe proibir ou ordenar qualquer coisa" (JAEGER, s/d: 62).

Contudo, se nos dispusermos a olhar para a obra de Homero como a história de alguém que, por fortes motivos -profissionais, no caso-, teve de ausentar-se de casa e, na tentativa de voltar, foi encontrando cada vez mais e mais obstáculos até que finalmente conseguiu regressar ao lar, provavelmente nos sentiremos muito mais 
próximos dele do que se olharmos para Ulisses como o grande herói, modelo das virtudes e qualidades aristocráticas de Grécia antiga.

Nós, como Ulisses, já tivemos de enfrentar decisões e escolhas difíceis. Como Ulisses, deixamo-nos enganar e seduzir ou fomos enganados e seduzidos, e, mesmo sabendo que aquilo não era o que queríamos, mesmo tendo a certeza e a vontade de sair daquele lugar e voltar ao que verdadeiramente era nosso, também como Ulisses nunca encontrávamos força para cortar e sair daquela situação.

Também já tivemos a experiência de "perder a cabeça", de estar numa situação limite, de sentir-nos sobre um abismo sem ter a quem recorrer e, provavelmente, também tivemos a experiência de ter sido socorridos no último momento por uma mão divina, por um amigo ou por um acaso.

Talvez a "chave de leitura" que nos ajude e anime a ler essa obra clássica seja ter em conta que "Odisseia" significa "A biografia de Odisseu”, ou, se quisermos, "A história de Odisseu”. O nome grego da personagem central da obra era Odisseu e, por isso, a sua história é a “Odisseia”. Ulisses é o nome latino e é o que prevaleceu.

Todos somos Ulisses ou todos somos Odisseu. E é sobre isso que vamos falar. Não sobre as qualidades do herói grego, nem sobre os seus mitos nem os seus valores. Mas sobre a experiência humana vivida por um grego do século -VIII, chamado Ulisses, porque o seu avô, Autólico, assim quis que fosse o seu nome, porque, ele, o avô, que mais do que herói era um ladrão violento, quis dar-lhe um nome que lembrasse a "fúria", porque, afinal, tinha feito muitas maldades e tinha "causado sofrimentos a muitos, a homens e a mulheres" (Canto XIX, v. 407-8: 455).

\section{Quem é Ulisses?}

O primeiro contato que temos com Ulisses é com a figura de um homem derrotado. Poderá ter sido o grande estrategista de Tróia e poderá ter se comportado como um valente guerreiro, contudo quando Homero nos apresenta Ulisses na ilha de Calipso, vemos um homem que não tem forças para sair da situação em que está.

De manhã, passa o tempo olhando para o mar, sonhando com a sua terra natal e consumindo-se de vontade para voltar, porém, quando chega a noite, toda essa força de vontade se desvanece perante os encantos e a sedução de Calipso.

Encontrava-se 
sentado na praia, os olhos nunca enxutos

de lágrimas; gastava-se-lhe a doçura de estar vivo,

chorando pelo retorno. E já nem a ninfa lhe agradava.

Por obrigação ele dormia de noite ao lado dela

nas côncavas grutas: era ela, e não ele, que assim o queria.

Mas de dia ficava sentado nas rochas e nas dunas,

torturando o coração com lágrimas, tristezas e lamentos (Canto V, 151-157: 200).

Há muitas Calipsos na vida de cada pessoa. Calipso significa "A que oculta". Pessoas, situações e coisas que subjugam a nossa vontade e que ocultam as suas garras e as suas correntes e das quais dificilmente conseguimos libertar-nos. Sonhos, ambições e gostos que acabam por obcecar-nos e nos dominam ${ }^{1}$.

Todos, provavelmente, teremos tido a experiência pessoal a que Hanna Arendt se refere quando falava que o ato da vontade é um ato duplo, à diferença do ato do entendimento, que é simples e único. Quando queremos algo, temos a experiência de que, simultaneamente, queremos também muitas outras coisas ${ }^{2}$. E a experiência de que se queremos algo, então, necessariamente teremos de não querer todas as outras coisas que não são esse algo. É uma experiência dilacerante. Queremos e não queremos esse algo, porque não queremos deixar de querer tudo o mais. Queremos esse algo e não queremos tudo o mais, porém, na hora da execução, não hora da renúncia, de deixar de lado tudo o mais, todos temos experiência de que muitas vezes acabamos querendo o que não queremos. Arendt fazia referência às palavras de São Paulo na sua carta aos Romanos: "Não entendo o que faço: porque não faço o que quero, mas faço aquilo que não quero". (ARENDT, 2009: 327-335)

Ulisses queria voltar para a sua terra e a sua família, contudo não tinha forças para livrar-se da sedução e da submissão a Calipso. E essa situação de submissão, de não ter forças para fazer o que verdadeiramente queria, em definitivo, essa situação de não ser quem, de verdade, se é, já durava sete anos. E, durante todo esse tempo, Ulisses consumia-se, como nós, pela saudade.

Foi preciso que Palas Atena, a filha de Zeus, intercedesse por ele e enviasse um mensageiro, Hermes, para que comunicasse a Calipso que a vontade de Zeus era que

\footnotetext{
${ }^{1}$ Sobre esse tema, talvez seja interessante ler a obra de HAN, 2015, principalmente o cap. 4, Vita activa, em que estabelece um diálogo com a obra de Hannah Arendt, A condição humana.

2 Arendt fala que a todo ato de vontade corresponde uma "contravontade", se não fosse assim, não poderíamos sequer falar em liberdade. Cf. ARENDT, 2009: 331 e 332.
} 
deixasse livre Ulisses para que pudesse retornar à sua terra e aos seus familiares (Canto V, 30-42: 196).

Quando se discute sobre o que é o homem, a discussão própria da questão "coisifica" o homem, torna-o estático demais. Falamos que o homem é isto ou aquilo ou mais aquilo outro e perdemos a dimensão do devir, do vir a ser, do processo histórico, da autorrealização. É como se estivéssemos falando de um homem que, como dizia o filósofo espanhol Unamuno "não é daqui nem dali, não tem carne nem osso. Ou seja, um não-homem" (UNAMUNO, 1901: 9).

Quando se fala de Ulisses, como faz Homero, falamos de alguém com história, com biografia, com uma família e de um lugar determinado e que, ao longo dos anos, realizou atos mais ou menos honestos, mais ou menos vergonhosos, mais ou menos heroicos. Alguém que gostaria de poder fazer algumas coisas, mas não encontra forças para realizá-las. Ou de alguém que umas vezes encontra essa força e outras, não. O homem, como dizia o filósofo espanhol Julián Marias é alguém que tem uma natureza dinâmica. O homem é sendo. ${ }^{3}$

Contudo, o decisivo aqui, quando falamos do homem de carne e osso não é apenas o "sendo", mas o fato de que dependendo de como for, ou seja, dependendo das escolhas que realizar, dos atos que praticar e das tarefas que levar ou não levar a cabo, o homem será mais ou menos humano, se aperfeiçoará mais ou menos, será melhor ou pior. Se humanizará ou se desumanizará.

É disso que a Odisseia trata. Trata de como Ulisses umas vezes foi um bom homem, outras, um péssimo homem, algumas vezes foi heroico e muitas outras vezes foi apenas mais um dentre os muitos homens que estiveram em Tróia. É isso que é um herói? Provavelmente, não, ou pelo menos, não na acepção que o termo tem atualmente, mas, do ponto de vista que interessa para esse artigo, a obra de Homero trata sobre como se faz e se constrói um homem.

A "história de Ulisses" é a história de um homem que se encontra fora do seu lugar. Conta de um homem que morre de saudades por voltar à sua casa e à sua família, que gostaria de fazer o que fosse preciso para reunir-se com os seus e reencontrar sua terra e o seu lugar, porém, a cada noite que passa sente que lhe falta a força de vontade para que esse "gostaria de voltar" se transformasse num "voltou".

\footnotetext{
${ }^{3}$ Marías refere-se ao fato de que a vida "é sempre nova" e, nesse sentido é de uma "radical inovação". A vida nunca está dada e é sempre vivida e, nesse sentido, podemos ir descobrindo quem somos na medida em que nos acontecem coisas ou vamos respondendo aos apelos da vida. Cf. MARÍAS, 1988: 270 e 276.
} 
Ulisses está, quando começamos a ler os cantos, onde não quer estar. Vive uma vida que não é a vida que tinha sonhado em viver, nem a vida que quereria viver. O que ele quer é poder voltar para Ítaca, porque é lá que pode verdadeiramente ser quem ele é: rei da ilha, esposo de Penélope, pai de Telêmaco, filho de Laertes. É lá que Ulisses é quem ele é. E é por isso que precisa voltar para ser quem ele é. Esse retorno, esse longo processo de volta a casa, essa odisseia é o aprendizado de cada homem para ser verdadeiramente humano. Todos precisamos de uma odisseia para sermos quem gostaríamos de ser, quem verdadeiramente deveríamos e poderíamos ser.

A Odisseia nos fala não apenas de quem Ulisses é, mas, principalmente, de quem gostaria de ser, quem deveria ser. Essa é a grande intuição grega sobre a condição humana. O homem não é o mesmo que uma pedra, uma árvore, um cachorro, um cavalo... O homem está num nível distinto de todas as outras coisas da Natureza. Nas palavras de Jaeger, o que importava verdadeiramente aos gregos não era o "individualismo", mas o "humanismo" e, portanto, preocuparam-se com "a educação do homem de acordo com a verdadeira forma humana, com o seu autêntico ser" (JAEGER, s/d: 13). Essa é a razão e o motivo da Paideia.

Ulisses é alguém que, principalmente, sonha, sente saudade, sente remorso, se dói e se arrepende de tudo o que fez de errado e chora porque se sente incapaz de executar aquilo que gostaria de ser e de realizar. Sonha com outra vida, aquela que seria a sua verdadeira vida, mas enquanto sonha, vive enredado no encanto de Calipso.

A Odisseia é a primeira narrativa consistente que nos fala do processo de aprendizado de um homem concreto, de Ulisses de Ítaca. Mas não o aprendizado técnico ou profissional -onde aliás, Ulisses era um dos melhores- mas o aprendizado mais importante e mais necessário para qualquer ser humano. Na sua odisseia, Ulisses aprendeu, depois de um longo processo por muitos anos, a comportar-se como um bom homem, como um bom ser humano.

\section{A condição humana}

Todos temos experiência da nossa própria fragilidade e, ao mesmo tempo, todos temos uma ideia, mais ou menos acertada, das nossas próprias forças. Cada vez é mais comum encontrarmo-nos com pessoas que se, por um lado, têm uma enorme competência profissional - Ulisses era, de fato, um dos melhores e mais engenhosos 
guerreiros, juntamente com Aquiles- por outro lado, são extremamente frágeis diante de quaisquer outras dificuldades que estejam além das profissionais ${ }^{4}$.

O retrato que Homero faz de Ulisses é o de uma pessoa que ainda não amadureceu por completo. É sem dúvida um ótimo guerreiro, é extremamente habilidoso e engenhoso. Sabe sair-se bem em todas as empreitadas que de uma forma ou outra estão relacionadas com a guerra. Contudo, seu filho Telêmaco tem de sair à sua procura porque, depois de tanto tempo, não deu ainda notícias para a sua família; a sua mulher, Penélope, tem que inventar cada dia uma nova maneira de ir aguentando a pressão de mais de cem pretendentes que querem ocupar o lugar de Ulisses. E ele, Ulisses, encontra-se dividido de forma quase neurótica entre o que gostaria de fazer voltar para a sua terra e a sua família- e o que, de fato, faz -ficar morando com Calipso.

$\mathrm{O}$ que foi que o mundo grego descobriu com respeito à condição humana? Jaeger, ao falar sobre a formação clássica do mundo grego, observava que, ao longo dos séculos, os gregos descobriram que todos os seres criados (os minerais, as plantas e os animais) estavam capacitados com todas as faculdades e virtualidades que os ajudariam a chegar à sua realização e à sua perfeição. Contudo, no caso do ser humano a sua realização passava por um longo e demorado processo de educação. Tinham inteligência para conhecer a verdade das coisas e, mais ainda, para descobrir soluções inesperadas para as situações difíceis que a vida apresentava; tinham vontade para querer o bem e afastar-se do mal; tinham sentimentos para, dependendo precisamente dessa educação, desenvolver ainda mais e melhor a sua inteligência e vontade. E tinham -que é o que nos interessa aqui- um conjunto de virtudes em estado embrionário que poderiam ser desenvolvidas e, mais, tinham a capacidade de adquirir aquelas virtudes de que careciam.

A grande descoberta grega foi perceber que a vida não era um problema e que, portanto, o ser humano não precisava sair à procura de soluções. A vida era um drama e, portanto, precisava ser vivido ${ }^{5}$ E para vivê-la era preciso suportar a existência e, à medida que o homem fosse suportando a vida, acabaria aprendendo a vivê-la como ser

\footnotetext{
${ }^{4}$ Sobre este tema pode ser interessante a obra de ILLOUZ, 2007.

${ }^{5}$ Seguindo nessa tradição, Julián Marías defende que a vida humana tem uma estrutura dramática e não problemática. Cf. MARÍAS, 1994.
} 
humano. E aprenderam que o homem tinha mesmo capacidades para viver o drama da vida. A essas capacidades os gregos deram o nome de virtudes ${ }^{6}$.

Se a vida fosse um problema, a questão humana seria ter conhecimento técnico. Mas se a vida for um drama, então do que precisamos é ter uma estrutura interior de virtudes, que nos ajudem a viver a vida que temos.

E as virtudes só se adquirem com os atos praticados. E, de acordo com o poema, a melhor forma de desenvolver a estrutura virtuosa seria por meio da dor e do sofrimento.

No Canto XIII, 310, há um diálogo crucial entre Ulisses e Palas Atena. Ulisses tinha passado por um sem-fim de obstáculos, dificuldades e sofrimentos e, mesmo assim, quando já estava prestes a realizar os seus sonhos, porque tinha acabado de chegar a Ítaca, Atena lhe diz que ainda não, que é preciso ainda esperar um pouco mais, sofrer um pouco mais. Por outras palavras, Atena está advertindo aos gregos que a escutam que, se quiserem ser verdadeiramente humanos, devem aprender a serem pacientes.

\section{Saber padecer}

O começo da Odisseia não deixa muito espaço para a dúvida. Começa dizendo que vai contar "o retorno do sofredor Ulisses. Que ele regresse numa jangada bem atada aguentando sofrimentos" (Canto V, 3-33).

E se ainda houver dúvida, os 5 primeiros versos do Canto I avisam que se irá falar de um homem que no meio de uma vida de intenso sofrimento, tentando salvar a sua vida e a dos seus amigos, perdeu-os todos e só depois de 20 anos, conseguiu voltar para casa.

Foi assim que Ulisses tornou-se um ser humano melhor. Por meio da dor, do sofrimento e da paciência que foi adquirindo à medida que ia suportando as dificuldades e superando os obstáculos. Umas vezes vencendo-os e, outras, sendo derrotado. Não há outra forma de ser paciente a não ser sofrendo aquilo que nos acontece. Em grego, paciência - de pathos- significa isso mesmo: a capacidade de sofrer e de suportar as circunstâncias e os acontecimentos que a vida nos apresenta.

\footnotetext{
${ }^{6}$ A expressão grega era "kalos kagathos" significando o bom e o belo. Todo o processo de formação e educação do homem tendia a desenvolver aquelas qualidades que, uma vez arraigadas, poderiam servir para qualificar alguém com um "homem bom".
} 
Podemos estranhar-nos de que as coisas sejam dessa maneira e questionar-nos sobre o porquê deveriam ser assim. Por que os gregos achavam que, para que houvesse um desenvolvimento e um aperfeiçoamento adequado do ser humano, era preciso aprender a ser pacientes?

Homero não responde de forma conceitual, mas o faz por meio de um poema, responde contando a vida e a história do sofredor Ulisses. Há, contudo, uma peculiaridade importante na estrutura do poema. É o próprio Ulisses quem nos conta -e conta ao Rei dos Feácios- tudo o que teve que sofrer na vida desde que saiu de Tróia. E isso nos leva a pensar que, para ganhar paciência, não se trata apenas de aguentar e sofrer com as vicissitudes da vida, mas que é preciso também refletir sobre o que nos foi e nos vai acontecendo. Só assim, quando me questiono sobre porquê isto teve que acontecer comigo é que posso dar-me conta do processo de maturidade, do longo percurso de formação para chegar a ser mais humano.

Cada um dá uma resposta, muitas vezes bastante diferentes. Ivan Karamazov revoltou-se não com a vida, mas com o próprio Deus que permitia que o mundo fosse tão injusto e, inclusive, deixava que sofressem pessoas inocentes. Frodo queixou-se de que as coisas no seu Condado fossem tão difíceis e que os tempos fossem tão negros, mas enfrentou o desafio e se tornou o portador do Um Anel. D. Quixote, inconformado com as injustiças e as situações tortas e corruptas que percebia ao seu redor, saiu da sua casa para endireitar as coisas. Hamlet resmungava do sem sentido do mundo e de como as coisas estavam tortas e se queixava porque via que tinha que ser ele quem deveria consertá-las... Cada um responde à sua maneira e é precisamente cada resposta que damos que acaba por configurar o nosso caráter, a nossa personalidade e a nossa maneira de ser. Humanos ou desumanos, mais humanos ou mais desumanos.

A narração dos nossos atos e da nossa vida -o fato de contar-nos a nós próprios ou aos outros aquilo que fizemos ou deixamos de fazer- é precisamente o que nos possibilita de reconhecer, ou não, os nossos erros e nossos acertos, e a responsabilidade que tivemos. E para isso necessitamos -como necessitou Ulisses- de dois elementos que andam em falta atualmente: tempo e espaço. Tempo para pensar, refletir e tomar consciência. E lugar adequado para poder contar a nossa história.

Ao contar a sua história para Alcino, o Rei dos Feácios, a partir do Canto IX, ficamos sabendo como foi que Ulisses chegou até a ilha de Calipso, como ficou preso ali e como, depois de deixar a ilha em direção a Ítaca, andou à deriva pelo Mediterrâneo pela sua própria culpa. Houve lugares a que chegou e fatos que realizou mais ou menos 
importantes, mas, nas suas próprias palavras, houve quatro momentos que o marcaram para sempre, onde aprendeu mesmo com a experiência.

\section{A luta contra Polifemo}

Antes de chegar à ilha dos Ciclopes, Ulisses conta como andou por outros lugares, logo depois de abandonar Tróia, "onde saqueei a cidade e chacinei os homens e da cidade levei as mulheres e muitos tesouros, que dividimos" (Canto IX: 40). Quando chegaram onde moravam os Ciclopes, foi talvez um dos momentos em que melhor se deu na vida.

A situação era realmente complicada e difícil. Depois de uma dura e penosa viagem de barco em que estiveram a ponto de naufragar, chegaram a uma ilha e, nela, encontraram uma caverna com cabras, cordeiros e queijo. E foi lá que repuseram as suas forças.

O que não sabiam era quem morava naquele lugar. Quando o dono da caverna, Polifemo, entrou, rolou uma pedra enorme fechando a entrada. Ulisses quis acolher-se à proverbial hospitalidade grega e pediu-lhe comida e lugar para descansar, mas Polifemo agarrou um dos seus homens e, como ele mesmo disse, para mostrar de que tipo era a sua hospitalidade, devorou-o na hora, avisando que, no dia seguinte, comeria mais alguns, e depois mais alguns até que não sobrasse ninguém (Canto IX, 289-293).

De fato, logo de manhã, devorou mais dois gregos e Ulisses, cheio de cólera, teve intenção de tentar matá-lo, mas se conteve ao dar-se conta de que se o matasse, acabariam morrendo da mesma forma, porque não conseguiriam remover a pedra da entrada. Precisavam da ajuda do próprio ciclope para saírem vivos da sua cova.

É nessa hora que o poema nos descobre a esperteza de Ulisses. Ofereceu a Polifemo o vinho que trouxeram consigo, dizendo-lhe que era uma bebida própria dos deuses. O monstro gostou do gesto e do vinho e perguntou qual era o nome de quem lhe dera tal bebida, Ulisses respondeu:

- Ninguém é como me chamo. Ninguém me chamam a minha mãe, o meu pai, e todos os meus companheiros.

Assim falei; e ele respondeu logo, com coração impiedoso: Será então Ninguém o último que comerei entre os teus companheiros: será esse o teu presente de hospitalidade" (Canto IX: 366-370). 
Polifemo embebedou-se e acabou adormecendo. Ulisses e seus homens pegaram um galho de árvore, aqueceram-no no fogo, deixando-o pontiagudo e, enquanto Polifemo dormia, enterrou o galho no seu olho, deixando-o cego. Quando Polifemo começou a gritar, os outros ciclopes da ilha acorreram para a sua caverna e perguntaram o que estava se passando: “- Ó amigos, Ninguém me mata pelo dolo e pela violência! Respondeu" (Canto IX, 408).

E todos os outros ciclopes retiraram-se, pensando que estava doido e que Zeus lhe tinha enviado alguma doença.

Quando na manhã seguinte Polifemo, já cego, retirou a pedra para deixar que suas cabras e cordeiros fossem pastar, Ulisses juntou os cordeiros três a três e cada um dos seus homens saiu agarrado ao ventre do cordeiro do meio, de maneira que Polifemo, que tocava e apalpava os cordeiros que saíam não conseguiu perceber que os gregos conseguiram fugir.

Parece que fez tudo certo. Foi astuto. Enganou Polifemo e salvou seus homens. Mas Ulisses percebeu, depois que o tempo passou e que pode com calma pensar em 12 tudo o que havia acontecido na ilha, que cometera um erro grave e era disso que estava falando.

Onde foi que errou? Quando já estava a salvo, na nave, e Polifemo não podia mais saber onde é que estavam, Ulisses quis deixar a sua marca. Gritou-lhe e atraiu-o até a praia. Os seus companheiros ficaram apavorados e pediram-lhe para que calasse, mas o seu orgulho quis falar mais alto. Com o coração enfurecido, provocou e humilhou Polifemo: “- Ó Ciclope, se algum homem mortal te perguntar quem foi que vergonhosamente te cegou o olho, diz que foi Ulisses, saqueador de cidades, filho de Laertes, que em Ítaca tem o seu palácio" (Canto IX: 502-505).

O orgulho e a vaidade criam raízes fundas no ser humano. É difícil, muito difícil mesmo, para quem é orgulhoso, não querer se mostrar. É talvez uma das forças mais poderosas contra a qual o homem carece de forças. Não é fácil ser humilde, deixar barato e sair de cena sem procurar desesperadamente o elogio e o reconhecimento por parte dos outros. E mais difícil ainda quando se faz a coisa certa e na hora certa. E, ainda por cima, nos damos bem.

O que fez Polifemo? Começou a arrojar pedras enormes contra o navio e a invocar a proteção do seu pai, Poseidon, para que levantasse uma enorme tempestade e todos naufragassem e morressem. Não aconteceu assim porque Palas Atena, que 
protegia Ulisses, suplicou a ajuda de seu pai, Zeus, que, de fato, protegeu os gregos, mas deixou-os naufragando e à deriva ao longo do Mediterrâneo.

Há um dado interessante: o avô Autólico deu-lhe esse nome, Odisseu, porque significa homem irado, furioso, que causa sofrimentos e maldades aos outros homens...Ulisses é mesmo um orgulhoso. E por causa do seu orgulho, todos os seus outros companheiros acabarão morrendo mais tarde. Precisava cair na real. Mas não foi dessa vez.

Saiu-se bem, deu tudo certo e continuou cheio de si. Tinha ainda um longo caminho pela frente para saber o que era a humildade. Precisava, portanto, aos olhos de Palas Atena, continuar sofrendo. Sofrendo pacientemente até que aprendesse.

\section{O canto das sereias}

Depois de algumas outras vicissitudes acabaram aportando na ilha de Circe quem, entre outras coisas, tinha uma droga com o poder de fazer que os homens esquecessem da sua pátria e, com um toque da sua vara, transformava-os em porcos que encerrava nas suas pocilgas.

Alguns resistiram e quiseram fugir imediatamente, mas Ulisses não quis abandonar seus outros companheiros e voltou sozinho até o palácio de Circe. Antes de entrar, o deus Hermes saiu-lhe no caminho e deu-lhe uma erva que lhe serviria contra a droga de Circe.

Quando se encontraram, depois de Circe perceber que não conseguia enfeitiçá-lo nem o transformar em porco, Ulisses exigiu dela que devolvesse os seus homens, coisa que Circe fez e, ainda mais, deu-lhe alguns conselhos, dentre eles três que eram decisivos.

Primeiro, teria de descer ao Hades e encontrar-se com os mortos e principalmente com Tirésias, com quem de fato se encontrou e o advertiu para não chegar sequer perto da Ilha do Sol e muito menos para não ficar nela nem tocar nos enormes rebanhos que havia, pois tudo era do deus Sol e o castigo seria terrível. 
Em segundo lugar, teria de tomar extremo cuidado ao passar perto das Sereias porque, com o seu canto, atraíam as embarcações e prendiam os homens até morrerem e, por último, teria de decidir como se comportar ao passar entre Cila e Caríbdis, porque de ambos os lados poderia encontrar a morte de todos.

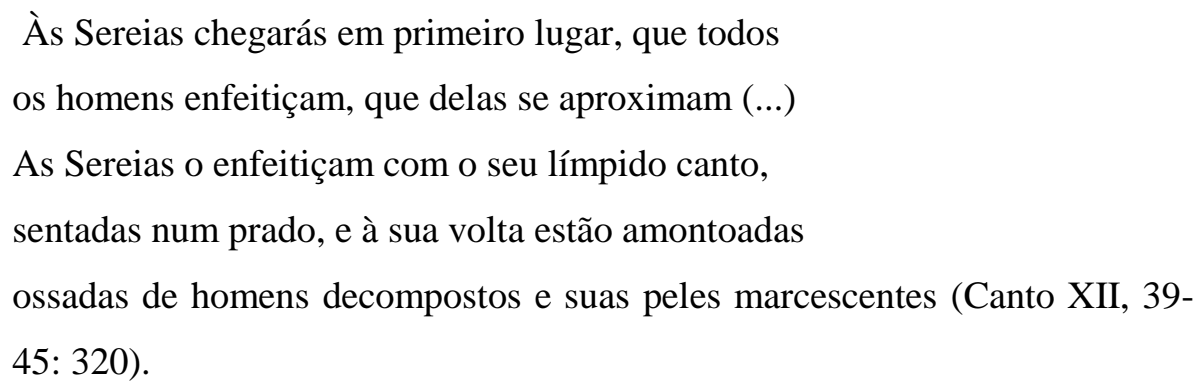

Diante do encanto, sentimos um forte desejo e vontade de "deixar-nos encantar", de poder ter, ouvir, tocar, estar junto, possuir, desfrutar.... Se não fosse assim, não nos encantaria. Contudo, sabemos por experiência que há coisas e, mais ainda, há atos e pessoas e situações que, além do prazer e do gozo que proporcionam, simultaneamente, dominam e subjugam nossa vontade, nossos gostos e nossos afetos e, a partir de certo momento, mesmo que queiramos, não conseguimos mais livrar-nos do seu domínio, muitas vezes despótico.

Como dizia Arendt, a estrutura da vontade é mesmo dupla, queremos o que nos encanta e, por isso mesmo, queremos tê-lo e desfrutá-lo e, ao mesmo tempo, não queremos ficar dominados por aquilo. Gostaríamos de poder ouvir as sereias sem ter como consequência vir a ser dominado por elas. Contudo, como Circe advertiu a Ulisses, é muito perigoso: quem se deixa encantar pelo seu canto, acaba preso na sua ilha e, no fim, apodrece.

O canto das Sereias além de ser doce e belo, ia direto no ego de Ulisses. Elogiavam-no, reconheciam-no como um dos mais famosos guerreiros de Troia e, além disso, prometiam-lhe o conhecimento das coisas futuras.

Vem até nós, famoso Ulisses, glória maior dos Aqueus!

Para a nau, para que nos possas ouvir! Pois nunca por nós passou nenhum homem na sua escura nau que não ouvisse primeiro o doce canto das nossas bocas; depois de se deleitar, prossegue caminho, já mais sabedor. Pois nós sabemos todas as coisas que na ampla Troia 
Argivos e Troianos sofreram pela vontade dos deuses;

e sabemos todas as coisas que acontecerão na terra fértil (Canto XII, 185-

191: 325).

Era preciso que Ulisses aprendesse a lição que não aprendera com Polifemo. O orgulhoso confia demais em si mesmo. Pensa que com ele sempre será diferente, que se os outros fracassam, erram ou, simplesmente, sucumbem e ficam subjugados, com ele não acontecerá, porque ele é diferente. Era preciso que aprendesse a não se deixar dominar pela presunção.

Ulisses colocou cera nos ouvidos dos companheiros, mas ele queria porque queria ouvir o seu doce canto. Teve, porém, um momento de lucidez. Pediu para o amarrarem no mastro, sem cera nos seus ouvidos, e advertiu-os que quando fizesse sinal pedindo para o desamarrarem, que não o obedecessem, mas, ao contrário, que remassem mais forte e rapidamente e que o amarrassem ainda mais fortemente ao mastro.

Quem é soberbo, quem é cheio de si e acha que pode tudo sozinho, que tem força de vontade suficiente para enfrentar qualquer obstáculo e resistir, sem deixar-se dominar, dificilmente faria como Ulisses. E se Ulisses não tivesse seguido os conselhos de Circe, e não tivesse confiado nos seus companheiros e desconfiado de si mesmo, dificilmente teria conseguido voltar para Ítaca. Estaria apodrecendo na ilha das Sereias. A sua presunção e o seu orgulho tê-lo-iam derrotado.

Há uns versos atribuídos a Eurípides, que nos permitem entender como os gregos olhavam para esse tipo de orgulho, de quem se acha superior aos outros e só confia em si mesmo:

Àquele a quem os deuses querem destruir, primeiro elevam-no ao monte mais alto da soberba, depois, embriagam-no de poder, cegam-lhe os olhos, enchem-no de solidão no meio de um mar de bajuladores, e quando finalmente ficam só, descobrem que não se suportam mais a si mesmos. Cair, então, é apenas uma questão de tempo.

Esse é o processo da hybris. O problema do homem, em certo sentido, é um só: medida e desmedida. A Hybris era a deusa que provocava a prepotência, a soberba, a arrogância, o desprezo, o descontrole, a fúria. Enquanto que a Nêmesis reconduzia os homens por meio da medida, moderação, humildade, sobriedade, calma e respeito.

É só isso. Cada um deixa-se guiar por Hybris ou Nêmesis. Só isso. 


\section{Entre Cila e Caríbdis}

Há situações na vida em que qualquer escolha é dolorosa. De maneira geral, toda escolha tem algo de doloroso, porque, voltando a Hannah Arendt, queremos muitas coisas. Muitas vezes até queremos tudo, porém, como somos humanos, uma escolha determinada implica a rejeição -que não queremos fazer, precisamente porque queremos tudo ou, pelo menos, queremos isto e o outro- de muitas, de todas as outras coisas. Se não for assim, a nossa escolha nunca se concretizaria.

Mas não foi essa a situação de Ulisses. Ele teria de escolher entre duas coisas horríveis, porque se não, não conseguiria voltar para casa. Contudo, como todo bom orgulhoso, não estava disposto a perder nada, a abrir mão de algo. Queria tudo e queriao precisamente como um desafio à sua força e ao seu valor. Era preciso que os homens soubessem que ele não era mesmo como os outros, que não precisava abrir mão de uma coisa para ter a outra.

No meio do caminho, levantavam-se dois rochedos. Num deles estava Cila, "ladrando de modo danado, (...) com seis pescoços muito longos e, sobre cada um, uma horrível cabeça, cada uma com três filas de dentes, grossos e cerrados, cheios de negra morte" (Canto XII, 87-92: 322).

No outro, encontrava-se Caríbdis, que três vezes por dia sugava toda a água do mar e três vezes por dia a vomitava, de maneira que a nau que se encontrasse por perto acabava sendo destroçada ao bater na rocha (Canto XII, 100-107: 322).

Circe, que o alertara sobre as sereias, também lhe disse que era arriscado e perigoso passar entre Cila e Caríbdis, mas teria de passar e, então, o melhor era aproximar-se de Cila, mesmo sabendo que perderia pelo menos seis dos seus homens, do que aproximar-se de Caríbdis, onde se perderiam todos com certeza.

É demorado vencer o orgulho e o amor próprio. Os conselhos de Circe soaram nos ouvidos e, mais, no ego de Ulisses como um desafio. Desta vez, Ulisses não estava disposto a agir como fez com as Sereias. Desta vez, sim, confiou na sua própria força e na sua sorte, mostrando-se teimoso e temerário e, por isso, resistiu aos conselhos de Circe.

Assim falou; a ela dei então a seguinte resposta:

Peço-te, ó deusa, que me digas com verdade se seria possível 
fugir da mortífera Caríbdis e repelir também a outra, quando fizesse dos companheiros a sua presa (Canto XII, 112-114: 322).

Circe volta a repetir-lhe que não é possível sair-se bem, diante de Cila e de Caríbdis, que será obrigado, por bem ou por mal, a se afastar o mais possível da segunda, e a fugir o quanto antes da primeira, que não teimasse em enfrentar Cila, armando-se para combatê-la, porque essa demora acabaria provocando a ira de Cila e, dando-lhe tempo, "voltará ao ataque com igual número de cabeças e levará novamente outros tantos homens" (Canto XII, 122-123: 323).

Mesmo assim, Ulisses não se conformou. Não é um único ato de virtude que é capaz de forjar em nós a virtude. Para que a virtude seja algo entranhado em nós, seja algo internalizado a tal ponto que seja parte da nossa maneira de ser, é preciso repetir uma e outra vez os mesmos atos. A boa desconfiança que teve de si próprio perante as Sereias, não se renovou perante Cila e Caríbdis, pelo contrário. Nesta situação, acreditou no seu arrojo, na sua astúcia e na sua força.

E, como o próprio Ulisses confessará, foi a mais terrível experiência que já teve em todos esses vinte anos de padecimentos no mar. "E ali à sua porta os devorou enquanto gritavam e estendiam para mim as mãos na luta de morte. Foi a coisa mais terrível que vi com os olhos de tudo quanto padeci nos caminhos do mar" (Canto XII, 225-233).

\section{A llha do Sol}

A última experiência, ainda mais terrível do que a anterior, aconteceu-lhe na ilha do Sol, "que aos mortais traz o deleite: pois é lá que reside o pior perigo de todos" (Canto XII, 274-275: 327).

O conselho que lhe fora dado por Tirésias, no Hades, era para evitá-la e, depois da experiência com Cila e Caríbdis, parecia estar decidido e, por isso, ordenou aos seus companheiros, com dor no seu coração, que continuassem remando com força e que não parassem. Mas não soube aguentar a pressão dos seus homens, que insistiam em ir lá e descansar. Não teve paciência para tanto.

O diálogo com o seu primo Euríloco é exemplar. Qualquer um de nós tem experiência de como é difícil resistir aos apelos emocionais, aos argumentos 
sentimentais, a essa pressão que se exerce sem violência, porém, com extremada força, quando quem nos fala é alguém muito próximo e querido.

És duro, Ulisses! Tens força em demasia, mas o teu corpo sente cansaço: na verdade, tudo em ti é de ferro, tu que não permites aos companheiros vencidos pelo cansaço e pelo sono desembarcar nesta ilha rodeada pelo mar, onde poderíamos preparar uma refeição saborosa; mas manda-nos assim vaguear pela rápida noite dentro, afastando-nos da ilha em direção ao mar brumoso (Canto XII, 189-285: 328).

Se tivesse aprendido com a experiência anterior, se tivesse se mantido na sua primeira decisão, teria insistido na sua ordem, mesmo provocando a reclamação e o descontentamento dos seus homens. Aí, sim, teria sido forte. Uma fortaleza que é ainda mais forte do que aquela fortaleza física à que Euríloco se referia.

Com frequência, é necessário ser forte para, procurando o bem do outro, saber resistir aos seus apelos, às suas chantagens emocionais, às suas reclamações diante da nossa dureza. É preciso saber dizer não, e manter esse não, quando vemos que dizer sim e ceder pode ser extremamente prejudicial para aqueles que não conseguem perceber a dimensão dos seus atos, quando levados pelo gosto ou pelo capricho ou pelo deleite.

Ulisses foi cedendo aos poucos. Primeiro, consentiu desembarcar na ilha, desde que os seus homens jurassem que se contentariam com os alimentos que lhes tinha dado Circe e que não tocariam em nenhuma vaca e nenhuma ovelha de toda a ilha, porque tudo ali era do deus Sol. Os homens juraram. Foi o suficiente para Ulisses ceder. Todos ficaram felizes e contentes e puderam descansar numa ilha maravilhosa, durante um mês (Canto XII, 297-325: 328-9).

Mas quando a fome começou a apertar, quando se acabaram os alimentos dados por Circe e os homens começaram a esquecer o que haviam jurado, aproveitaram um momento em que Ulisses se afastou deles para rezar a todos os deuses do Olimpo, e Euríloco arquitetou um argumento falacioso:

por mim prefiro morrer de um trago no mar, do que definhar lentamente numa ilha deserta (Canto XII, 350-1: 330). 
$\mathrm{E}$, sem pensar nem debater muito sobre o assunto, todos concordaram e imediatamente mataram as melhores vacas do Sol para comê-las. E assim passaram uma semana.

Ulisses, ao voltar e deparar-se com o acontecido, pediu perdão a Zeus, mas o Sol também tinha exigido reparação e uma "expiação condigna" (Canto XII, 381). Zeus não teve dúvida: quando os homens voltaram ao mar, provocou uma tempestade, os ventos e as ondas carregaram de volta a nau até Cila e Caríbdis, e com um único raio atingiu o mastro e a vela, projetando a nau contra Caríbdis. Não sobreviveu ninguém, apenas Ulisses que, depois de muito esforço e muitos dias à deriva sobre umas tábuas, chegou exausto à ilha de Calipso.

Ulisses não foi suficientemente forte. E o reconhece quando conta a sua história para os Feácios. Teria sido melhor se não tivesse ouvido os apelos de Euríloco, se se tivesse mantido firme em passar ao largo da ilha do Sol. Teria sido preferível desagradar a todos e ser acusado de duro de coração e de homem de ferro a ter que carregar depois com o peso da morte de todos sobre a sua consciência. Faltou-lhe fortaleza, então. Contudo, essa experiência e esse aprendizado, junto com o reconhecimento dos seus erros, foram precisamente as condições necessárias para, mais tarde, tornar-se verdadeiramente forte quando chegou a Ítaca e teve que ser paciente, prudente e humilde, aceitando as humilhações provocadas pelos pretendentes, esperando o momento oportuno para se revelar e atacar, sabendo dar tempo ao tempo.

É assim que ficamos conhecendo a história do que aconteceu com Ulisses e seus homens e de como chegou a ficar sob o domínio de Calipso. Tudo o que lhe aconteceu não foi suficiente para que amadurecesse. Normalmente, na hora em que as coisas nos acontecem, na hora em que estamos vivenciando a vida, dificilmente aprendemos aquilo que a própria vida está querendo nos ensinar. O processo de amadurecimento passa, sim, pela experiência, mas passa também pela reflexão. E isso requer tempo. Às vezes, muito tempo. Ulisses ficou sete longos anos junto de Calipso e, quando ficava a sós, olhando para o mar, pensava em tudo o que lhe acontecera. E chorava.

\section{O coração de Ulisses}

Nem sempre temos em conta, ao lermos a Odisseia, o transcurso do tempo. Quando os cantos começam, Ulisses já há sete anos que se encontra retido na ilha de 
Calipso. Teve tempo suficiente para pensar em tudo o que aconteceu com ele. Teve, principalmente, a dolorosa experiência de não ser tão forte assim como pensava. Sabe que, por mais que queira voltar para a sua terra e sinta uma forte saudade e vontade de rever sua mulher, seu filho e seus parentes, não tem força para deixar Calipso.

Depois, quando a partir do Canto IX começamos a ouvir a sua história contada por ele próprio, nem sempre percebemos que estamos ouvindo algo acontecido há mais de sete anos. Por isso, quando nos perguntamos sobre "quem é?" ou "como é Ulisses? só poderemos responder lendo toda a obra de Homero. Toda a vida de um homem não pode ser resumida em poucas palavras e, menos ainda, em alguns conceitos avaliativos. E muito menos ainda nos acontecimentos de alguns dias, meses ou anos atrás. Não há como responder à pergunta sobre "quem é Ulisses" com um simples "Ulisses é isto ou aquilo". É preciso ouvir a história que ele conta de si mesmo, o que é que ele pensa, depois de tudo o que aconteceu com ele, sobre si mesmo

Vemos que foi prudente e astuto porque soube encontrar, diante da ameaça do ciclope Polifemo, a maneira de se livrar dele; bem como também vemos que se deixou levar pelo orgulho, a presunção e a soberba, quando, uma vez a salvo na sua nau, provocou, insultou e humilhou Polifemo (Canto IX, 495-505: 274) . E também ficamos sabendo que antes disso dedicou-se à pilhagem das cidades, à matança dos homens e ao rapto das mulheres.

Vemos como soube arriscar a vida pelos seus companheiros, voltando ao palácio de Circe para resgatá-los e também vemos como não soube ouvir nenhum dos conselhos que a própria Circe lhe deu e, precisamente por isso, acabou perdendo esses mesmos companheiros.

No Canto XX, vemos um Ulisses extremamente paciente e sofredor. Assistimos ao monólogo de Ulisses consigo mesmo, pedindo ao seu coração para aguentar e ter paciência, porque "já aguentaste coisas muito piores" (Canto XX, 18: 463) e ficamos sabendo que "o coração aguentou, mantendo-se em obediência completa" (Canto XX, 23: 464). E vemos também como a sua deusa, Atena, não quis poupar-lhe todo o sofrimento possível, porque era conveniente que assim fosse.

não permitiu de modo algum que os arrogantes pretendentes se abstivessem de comportamentos ultrajantes, para que a dor penetrasse mais fundo no coração de Ulisses (Canto XVIII, 346-348: 438). 
E vemos ainda como, desta vez, Ulisses aprendera a lição e aceitou ser humilhado por pessoas que, por mais de três anos, acossavam e assediavam à sua mulher, ultrajavam todos os seus parentes, exploravam os seus bens e riquezas e só pensavam em matá-lo para ficar com Penélope e com o reino.

Por boca de Atena, que o conhece bem, sabemos que Ulisses era um "homem teimoso, de variado pensamento, urdidor de enganos" (Canto XIII, 293, p. 343), mas também por boca da sua própria mãe, Anticleia, que também o conhece bem, com quem Ulisses se encontrou quando desceu ao Hades, a mansão dos mortos, sabemos que ela morreu de saudade, da saudade dele, dos seus conselhos e "da brandura do seu coração" (Canto XI, 202-204, p. 303). E Penélope, quando finalmente ambos se reencontram, nos diz dele que sempre foi "em tudo o mais compreensivo dos homens" (Canto XXIII, 210: $518)$.

O próprio Ulisses reconhece que a sua coragem lhe foi dada pelos deuses, por Ares e Atena (Canto XIV, 216: 356) e foi curtida à base de uma grande quantidade de sofrimentos (Canto XIV, 215: 356). Vemos, de fato, como contra toda esperança e de forma corajosa, decide enfrentar o poder e a magia de Circe, para resgatar muitos dos seus companheiros e amigos que ficaram encurralados nas pocilgas, transformados em porcos. E por isso, não aceita a proposta de Euríloco para fugir da ilha e, mesmo sozinho, encaminha-se decididamente até o palácio de Circe (Canto X, 271-273).

E vemos também como depois de ter enfrentado e dado morte a todos os pretendentes, soube enfrentar, junto com o velho pai e o filho, praticamente todas as famílias de Ítaca (Canto XXIV, 516-545: 541-2).

Ulisses foi transformando-se, ao longo do tempo e, enquanto se transformava, ia formando o seu coração, criando aqueles sentimentos que são os adequados a uma vida dignamente humana.

\section{A ajuda dos deuses}

Talvez o que mais possa nos surpreender ao lermos a obra de Homero seja a profunda e estreita relação dos deuses com os homens. Há um certo preconceito quando se trata deste tema. Normalmente, criou-se a ideia de que os deuses gregos eram implacáveis, rigorosos, cruéis e que diante deles não cabia nenhuma opção livre aos 
homens. Todos estavam dominados pelo destino imposto caprichosamente pelos deuses do Olimpo ${ }^{7}$.

Contudo, quando lemos a Odisseia verificamos que as coisas não são bem assim. A primeira aparição em cena por parte dos deuses é para que Zeus, a pedidos da sua filha Palas Atena, se compadeça de Ulisses que se encontra contra a sua vontade na ilha de Calipso, e que todo dia chora desejando voltar para a sua casa, mas, porém, o pobre coitado não tem forças para resistir a Calipso... É uma mulher falando de outra mulher sobre um homem que se encontra seduzido. Será mesmo que os deuses são assim tão desumanos? E Zeus se compadece de Ulisses e manda a Calipso que o devolva à sua mulher.

É também Palas quem, na figura do jovem Mentor -daí derivará depois o termo "mentoria"- aparece no começo do poema a Telêmaco para animá-lo a virar homem e sair à procura do seu pai. E será ela -Palas/Mentor- quem o acompanhará nessa viagem para orientá-lo, ajudá-lo e protegê-lo.

É Palas quem aparece a Penélope, no fim, e lhe dá uma beleza deslumbrante que fará com que todos os pretendentes fiquem estáticos diante dela, coisa que, naquela hora, fazia parte da estratégia de Palas para que Ulisses adentrasse na sua casa e pudesse derrotá-los

E é Palas Atena a quem Ulisses dirige suas orações dando graças, pedindo ajuda, oferecendo sacrifícios e quem o protege ao longo de todo o seu percurso, a sua longa jornada de volta à casa, pedindo a seu pai Zeus que o protegesse e que não deixasse que morresse entre as ondas do mar.

É difícil acreditar que o grego que ouvia ou lia a Odisseia tivesse uma visão dos deuses como seres cruéis e desumanos que queriam apenas a submissão e o sofrimento de cada um deles.

Há um canto, o XIII, que é extremamente significativo da delicada e amorosa relação entre Palas e Ulisses, onde Palas se mostra tão divina quanto Ulisses humano. Ulisses, como muitos de nós, confia nela e, ao mesmo tempo, desconfia. Sabe que sempre o ajudou, e sabe também que ele próprio sempre rezou e pediu a sua ajuda, e, contudo, sente medo, perplexidade, dúvidas, até o ponto de não conseguir ter um sono sossegado e dormir tranquilo.

\footnotetext{
${ }^{7}$ Nesse sentido, fala-se em "sentir-se aplastado por uma Fatalidade desapiedada" ou em "ser marionetes de uma Fatalidade sobrenatural”. Cf. FESTUGIĖRE, 1986: 15 e 16.
} 
Quando Ulisses acabara de regressar a Ítaca, vemos como Atena se queixa e reclama de que não a tivesse reconhecido, mesmo estando sempre ao seu lado e cuidando dele:

..., Mas tu não reconheceste

Palas Atena, a filha de Zeus - eu que sempre

em todos os trabalhos estou ao teu lado e por ti velo" (Canto XIII, 299-301: $343)$.

Ulisses, então, pede à deusa para tecer um plano, de maneira que possa castigar a todos os pretendentes, e suplica para que fique ao seu lado. E Atena garante-lhe que lutará ao seu lado e que não o perderá de vista. Contudo, Ulisses não fica tranquilo. Seu coração é assaltado pela dúvida e pelo medo: será que conseguirá dar conta de todos os pretendentes? Só ele e Palas Atena? Será que só isso é suficiente?

Tudo o que disseste, ó deusa, foi na medida certa.

Mas ao espírito e ao coração me vêm preocupações:

como porei as mãos nos desavergonhados pretendentes,

um homem só, quando eles são muitos lá dentro" (Canto XX, 37-40: 464).

Não se trata, portanto, de uma confiança cega. Ulisses é tão humano, como tantos e tantos de nós, que mesmo tendo experiência da ajuda divina, sente a garra da incerteza e da dúvida no próprio coração. É inevitável. Não se trata nem de um herói, nem de um super-homem. Como é que, humanamente, vai derrotar, sozinho, cem homens fortemente armados?

E o mais interessante é que Atena não se impacienta, nem se irrita com a sua desconfiança. Pelo contrário, volta a acalmá-lo, volta a lembrar-lhe que sempre esteve do seu lado, e, delicadamente, aconselha-o e ajuda-o a dormir e descansar, dando-lhe esperanças de que tudo acabará bem:

Homem duro! Outro confiaria em amigo mais fraco,

um que é mortal e não é dotado de muitas ideias.

Mas eu sou uma deusa, que sempre por ti mantenho vigília em todos os teus

trabalhos (...)

Entrega-te agora ao sono. É coisa desagradável passar toda 
uma noite sem dormir. Estás prestes a sair do sofrimento (Canto XX, 45-53: 464).

Talvez, para o homem contemporâneo, todo esse mundo onde o humano se entrelaça com o divino não faça muito sentido. Shakespeare, na sua peça sobre "o bom Rei Henrique VI", expressou bem o sentimento de egoísmo e de isolamento característico do homem moderno, quando coloca nas palavras do futuro Ricardo III: "Eu sou eu mesmo, sozinho" 8 .

A premissa da sociedade contemporânea parte da ideia moderna de que o homem, com a sua razão e com a sua vontade, com a ciência e a técnica em contínuo progresso, não precisa de ninguém para tomar conta da sua própria vida. De certa forma, todos tendemos a pensar que cada um por si pode ter as rédeas da própria vida nas suas mãos, projetando o futuro e criando o seu próprio destino.

Ulisses não teria sido o que foi, nem teria conseguido realizar o que realizou se se tivesse empenhado em fazer tudo sozinho. Sempre contou não só com a ajuda de Palas Atena, mas também com o auxílio e os conselhos dos amigos que estiveram com ele na guerra de Troia e com muitas pessoas que se cruzaram na sua vida e de quem sempre recebeu ajuda. E não teria sido quem foi se não tivesse aprendido, por meio de imensa paciência e muitos sofrimentos, a ser quem verdadeiramente era: um homem humano.

\section{Fontes}

HOMERO (2011). Odisseia. Trad. Frederico Lourenço. São Paulo: Penguin-Companhia das Letras.

\section{Referências Bibliográficas}

ARENDT, Hannah (2009).A vida do espírito. Rio de Janeiro: Civilização Brasileira, Rio de Janeiro.

BYUNG-CHUL, Han (2015). Sociedade do cansaço. Trad. Enio Paulo Giachini. Petrópolis, RJ: Editora Vozes.

FESTUGIËRE, A.-J. (1986). La esencia de la tragédia griega. Barcelona: Ariel.

ILLOUZ, Eva (2007). Intimidades congeladas. Las emociones en el capitalismo. Trad. Joaquín Ibarburu. Madrid: Katz Ediciones.

\footnotetext{
${ }^{8}$ SHAKESPEARE, 1988: 123 (5.6.84)
} 
JAEGER, W. (s/d). Paideia. A formação do homem grego. São Paulo: Herder. MARÍAS, Julián (1988). La Felicidad humana. Madrid: Alianza Editorial. (1994). Mapa del mundo personal. Madrid: Alianza Editorial.

SHAKESPEARE, William (1988). The Complete Works, The True Tragedy of Richard Duke of York and the good King Henry the Sixth. Oxford: Claredon Press.

UNAMUNO, Miguel de (1901). Del sentimiento trágico de la vida. Madrid: Austral.

Artigo recebido em 20 de abril de 2019.

Aprovado em 31 de maio de 2019.

DOI: $10.12957 /$ intellectus.2019.36828 